\title{
La facciata della Basilica di San Pietro: connessioni tra Luigi Moretti e Alberto Carpiceci
}

\author{
Marco Carpiceci \\ Antonio Schiavo
}

Abstract

II tema della 'connessione' ha suggerito un confronto tra due architetti, entrambi grandi esponenti della Scuola di Roma del primo Novecento, ed entrambi non solo ascrivibili alla categoria giovannoniana di 'architetti integrali', ma anche a quella di 'architetti umanisti', personalità di ampio spessore culturale oltre all'ambito dell'arte edificatoria: Luigi Moretti (1906-1973) e Alberto Carpiceci (1916-2007).

Scopo del testo è infatti tentare di connettere due diversi modi di studiare a livello di analisi grafica e storia della rappresentazione, la 'componente michelangiolesca' della facciata della basilica di San Pietro in Roma, sia a livello progettuale che realizzativo.

Uno dei principali punti di tangenza tra i due architetti è la ricerca costante sulla figura di Michelangelo Buonarroti (1475-1564) nella sua più specifica accezione di architetto, ricerca che, in entrambi i casi, fu innescata dall'attività formativa diVincenzo Fasolo ( 1885 -1969), docente di Storia e Stili presso la Scuola Superiore di Architettura di Roma.

Parole chiave

Michelangelo Buonarroti, Basilica di San Pietro, storia della rappresentazione, analisi grafica, storia dell'architettura.

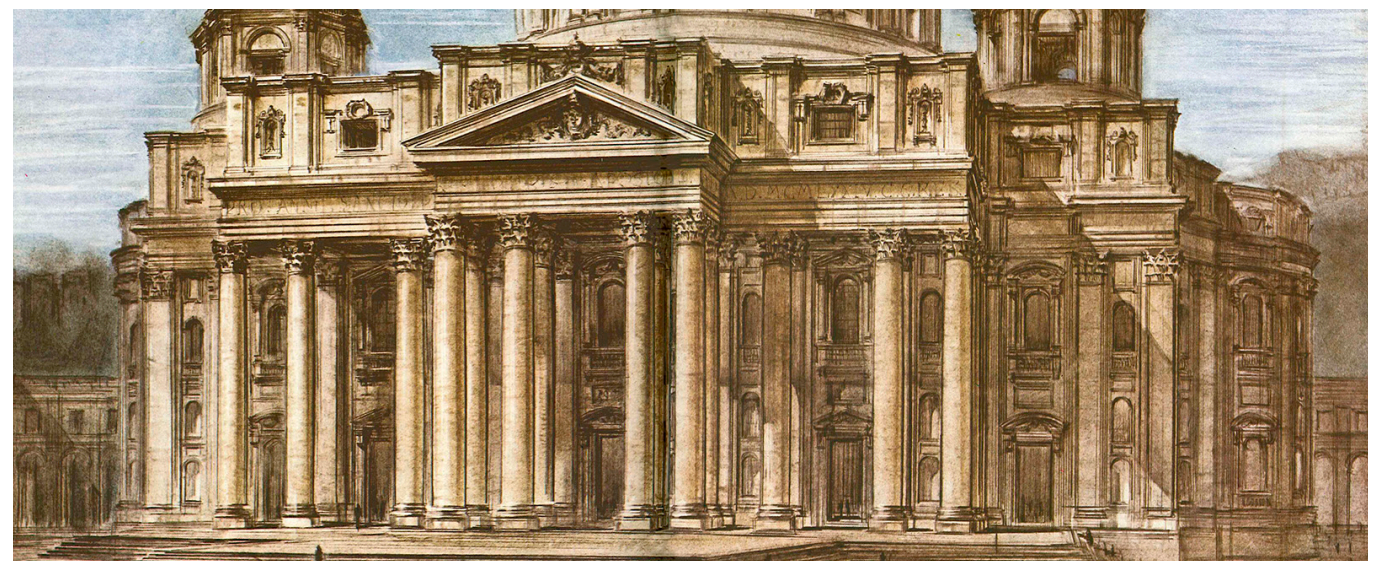




\section{Introduzione}

Il corso di Vincenzo Fasolo rappresentava un crocevia tra materie tecniche e teoriche, riflettendo chiaramente la visione della Scuola. Lo studio dei monumenti storici, visto come fondamentale approccio alla progettazione moderna, si riversava inesorabilmente nella pratica del disegno, e nel saper leggere l'architettura in maniera 'quadrimensionale', sfociando quindi in una prospettiva temporale dell'opera, che veniva come sezionata analizzando non tanto gli apparati decorativi, quanto i 'valori architettonici' e gli 'schemi ideali' della fabbrica. Fasolo non fu solo il Maestro di Moretti, e Carpiceci - del quale i due diverranno anche assistenti in seguito, seppur per un breve periodo - ma anche di altre fondamentali personalità come Mario Ridolfi (1904-1984), Bruno Zevi ( 1918-2000), Luigi Pellegrin (1925-200 I). Da Fasolo, come afferma Giorgio Muratore (1946-20 I7), nasce lo "spazio moderno romano" [Muratore $20 \mathrm{l} \mathrm{I}$ ], capace di sintetizzare le lezioni non solo di Michelangelo e del barocco, ma anche di Otto Wagner (|84|-19|8) e della sua Moderne Architektur.

Nel suo insegnamento venivano illustrati i "dati generali sull'evoluzione degli stili in rapporto alle esigenze e ai vari mezzi, con un carattere tecnico-stilistico, con speciale riferimento alla storia dell'architettura, prendendo in particolare considerazione l'organismo costruttivo dei monumenti e l'evoluzione delle forme architettoniche" [AA.W. 1926]. Fornendo quindi "non tanto condizioni generiche quanto disegni di schemi, lo studio nella forma più diretta ed efficace, delle masse e dei volumi" [Giovannoni 1932].

II tutto prende vita attraverso l'uso della geometria proiettiva, con le particolari rotazioni assonometriche che permettono di capire i segreti più intimi, e al contempo fondanti, dell'architettura, attraverso inoltre lo studio di quelli che Fasolo chiama "valori geometrici" [Fasolo 1954].

Fig. I. Luigi Moretti, Palazzo dei Conservatori, schema ideale della facciata michelangiolesca, 1927. Schizzo preparatorio per la tav. III.

Fig. 2. Luigi Moretti, Palaz zo dei Conservatori, organismo strutturale dell'edificio michelangiolesco, 1927. Schizzo preparatorio per la tav. IV.
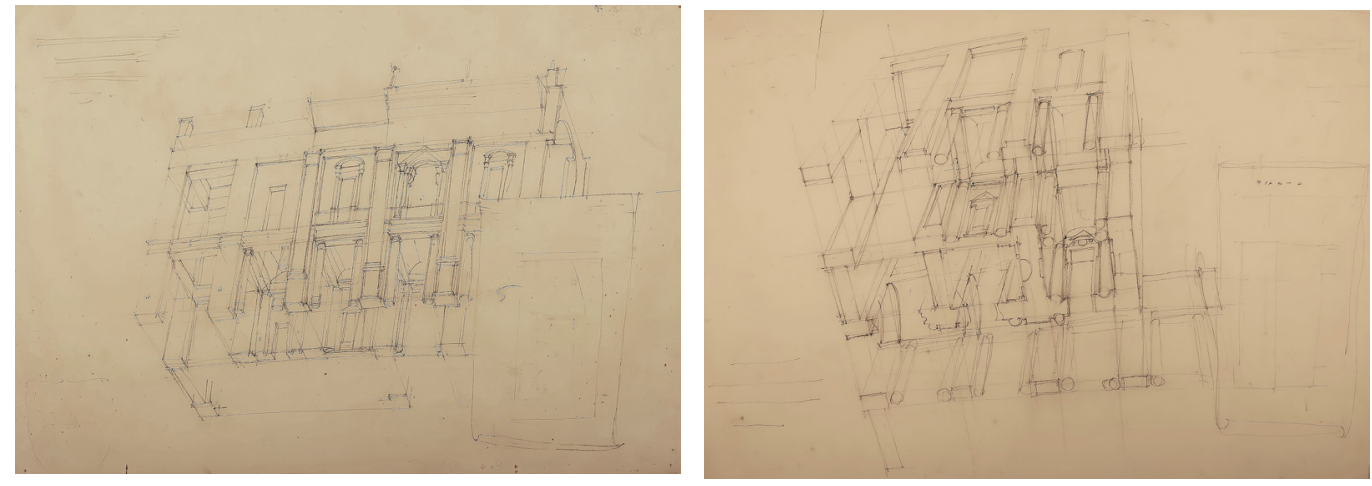

\section{Luigi Moretti: il sentimento costruttivo di Michelangelo}

Nell'ottobre del 1927 Moretti presentava per il corso di Fasolo una ricerca inerente all'architettura di Michelangelo e dei barocchi, il Canovaccio [Moretti 1927], elaborato scrittografico, diviso tra una parte teorica e delle tavole corredate da analisi grafiche. II documento è fondamentale per sviscerare la sua formazione culturale e grafica in relazione al docente spalatino. L'analisi dell'opera di michelangiolesca rappresenta il fulcro della ricerca, che verrà successivamente ripresa e approfondita nel 1964 in occasione della sua conferenza presso l'Accademia di San Luca [Moretti 1964], in cui verranno riproposti proprio alcuni disegni del 1927.

La figura di Michelangelo architetto è riscoperta a Roma a partire dagli anni Dieci e per tutti gli anni Venti proprio dall'attività culturale non solo di Fasolo ma anche di Gustavo Giovannoni (1873-1947), Giulio Magni (1859-1930), Corrado Ricci (1858-1934). Tuttavia, Moretti sembra percorrere una strada parallela ai due maestri riannodandosi col suo studio alle ricerche viennesi di inizio secolo, ad esempio quelle di Alois Riegl (|858-1905), il cui 
volume fu recensito da Antonio Muñoz (I 884-1960) nel 1908, pur considerando anche le pubblicazioni degli autori sopracitati, di Eberhard Hempel (1886-1967) e Dagobert Frey (I883-1962).

Nel Canovaccio Moretti introduce la sua idea sull'essenza dell'architettura basata sul "sentimento costruttivo come natura particolare dello animus dell'architetto in quanto tale", sentimento volto alla messa in evidenza degli elementi ideali fondamentali, da cui il concetto di costruzione come "realtà finale cui danno luogo i processi costruttivi" [Moretti 1927]. Tutti questi principi vengono esplicitati negli elaborati grafici che Moretti, ancora studente, redige appositamente, partendo sia da nozioni teoriche che da rilievi e disegni dal vero.

Nelle tavole III e IV (figg. I, 2) Moretti analizza il Palazzo dei Conservatori, architettura il cui schema ideale presenta maggiori assonanze con il progetto della facciata di San Pietro.

Nelle due diverse assonometrie dal basso, realizzate a matita e a china su carta gialla, si distinguono chiaramente gli elementi formativi dell'opera michelangiolesca: un'intelaiatura costituita da pilastri a tutta altezza e da relativi architravi gettati tra di essi in corrispondenza del primo piano e della terrazza; chiusura sul prospetto degli interpilastri al primo piano e conseguente predisposizione di due colonne al piano terra con funzione di rompitratta; realizzazione al piano superiore di finestre il cui arco di scarico in pietra si rivela nella sua parte come timpano arcuato - ipotizzando così l'origine degli stessi - e per questa parte sostenuto da due colonnine; la presenza del cornicione rende infine indispensabile un ulteriore rafforzamento dei pilastri attraverso delle lesene.

I disegni (figg. I, 2), leggendoli da sinistra a destra, rappresentano quindi la storia della concezione, o processo ideale, della fabbrica, che non solo si ripete nella lunghezza della facciata, ma anche nella profondità dell'edificio, in cui "l'incarnazione del sentimento costruttivo nella costruzione e di conseguenza l'identità tra processo ideale di formazione e processo di cantiere è quasi completa" [Moretti 1927]. E qui nasce il conseguente paragone con le grandi fabbriche della Roma Imperiale le quali "per la perfetta concezione architettonica sono anche modello come possibilità di esecuzione e razionalità di cantiere, in quanto il grande architetto romano nel processo ideale costruiva realmente di già" [Moretti 1927].

Interessante l'affermazione di Moretti, di come lo studio riveli un suo ragionamento personale filtrato dall'insegnamento di Fasolo: "premetto che quanto appresso dico, come d'altra
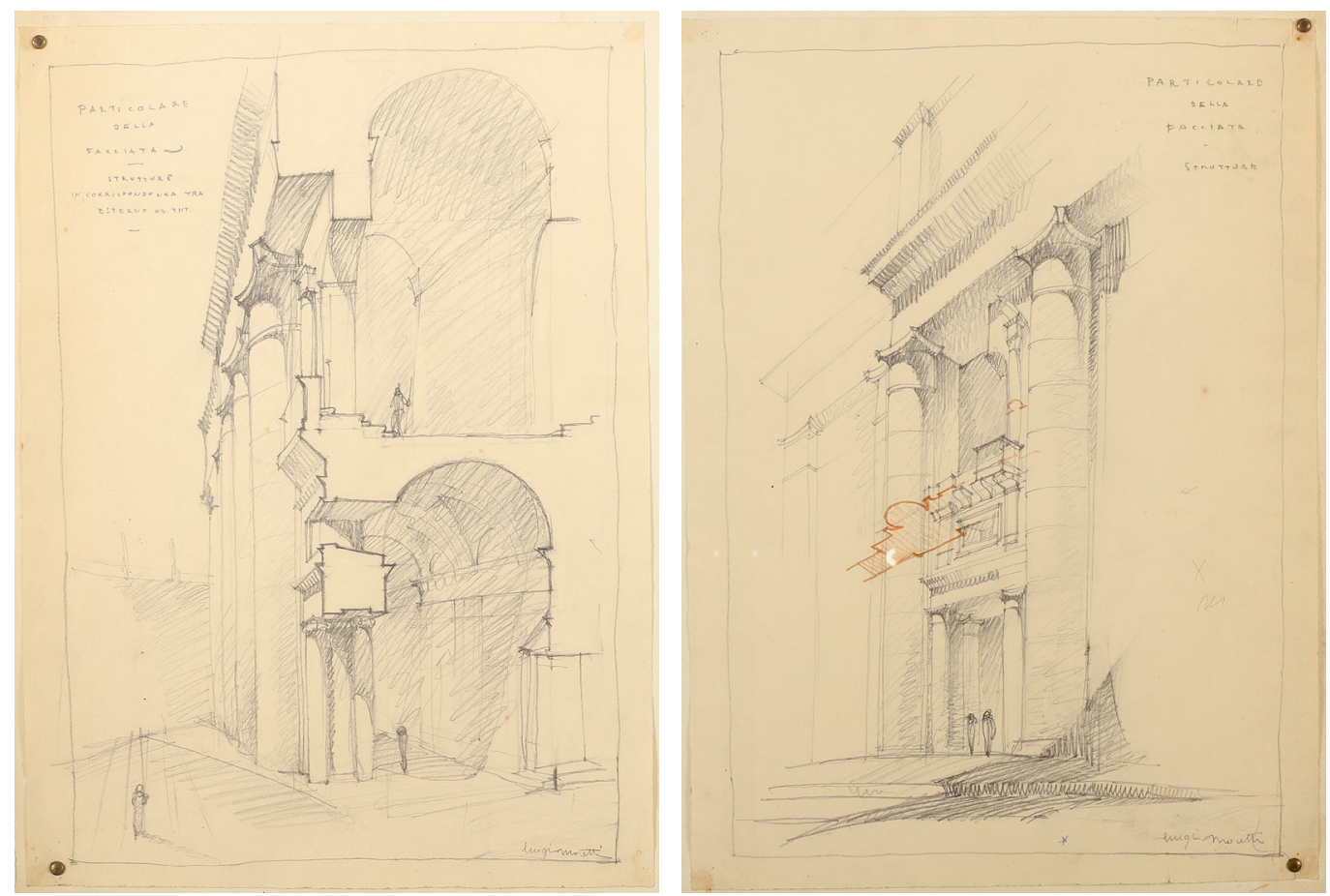
parte per tutto m'è nato spontaneo alla mente dalla osservazione ingenua e ammirata dell'edificio" [Moretti 1927], e proprio nel Palazzo dei Conservatori ne trovò "l'esempio più limpido di un regno rigorosissimo come rappresentazione intellettiva di strutture logicamente possibili" [Moretti 1957].

Il tutto sfocia conseguentemente nell'analisi della facciata di San Pietro. Com'è noto il progetto di Michelangelo venne alterato sensibilmente da Carlo Maderno (I 556- I629), tuttavia, dalle analisi grafiche di Moretti, il sentimento costruttivo della struttura ideale binaria del progetto michelangiolesco fu preservato, sintetizzando nel nuovo fronte il progetto originario dell'architetto fiorentino, con quanto quest'ultimo avesse già realizzato nel fronte meridionale della basilica.

Moretti realizza qui uno spaccato prospettico (fig. 3) di una parte dello schema costruttivo della facciata, mettendo in evidenza la linea di sezione: un disegno suggestivo nella sua semplicità e chiarificatore del suo pensiero. Segue un'altra prospettiva (fig. 4) in cui viene evidenziato un intercolumnio, la cui tridimensionalità è accentuata dall'uso del chiaroscuro realizzato con la tecnica del tratteggio. Infine, uno spaccato assonometrico (fig. 5) in cui viene sottolineato quello che Moretti chiama il sistema plastico-costruttivo, seguendo l'esempio del Palazzo dei Conservatori.

A corollario delle analisi grafiche Moretti afferma che "alla basilica viene immaginato un pronao in larghezza e altezza a essa uguale e formato secondo modello classico a colonne e architrave"; successivamente "il pronao viene mediante struttura secondaria indipendente dalla sua principale (le colonne) diviso in due per l'altezza da una volta a botte che si imposta dalla parte della fronte a livello della cornice" [Moretti 1927].

Riprendendo i suoi studi giovanili, nel 1964 approfondisce la questione affermando che "chi ereditò il pensiero della fronte templare porticata del progetto di Michelangelo per San Pietro, ne ereditò anche la maniera di traslarla, costruendola per nuove necessità. La struttura di Michelangelo è concettualmente intatta: tra le colonne potentissime, veementi, sono state costruite, ahimè, dagli umani e per gli umani, lasciando però libere e intatte le colonne, tra cui si incastrano, strutture libere che legano porte, balconi, finestre. In una costruzione idealmente indipendente, che ha frantumato lo spazio di Michelangelo contro Michelangelo, ma nel suo modo" [Moretti 1964].

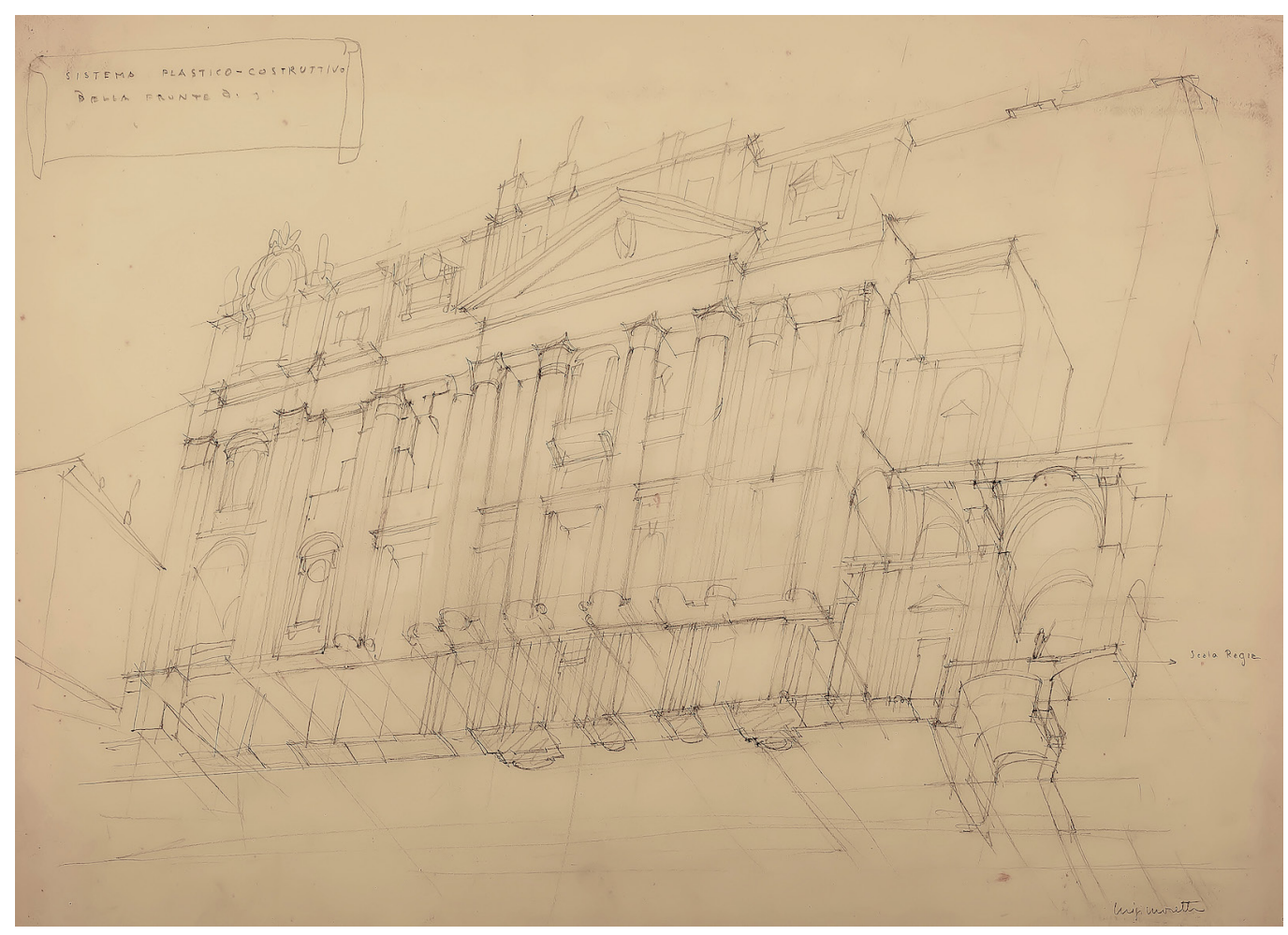




\section{Alberto e le sue visioni della facciata di San Pietro}

Negli ultimi anni Alberto Carpiceci (1916-2007) ripercorreva la sua esistenza realizzando degli album 'illustrati' dei momenti salienti della sua vita; o meglio di tutti quei momenti che lui ricordava come tali e che aveva deciso di testimoniare.

La 'rappresentazione' è stata sempre la struttura fondamentale della sua esistenza. Chiacchierone e fantasioso sì ma per ogni pensiero, per ogni fantasia, ci doveva essere un disegno. Non ricordo nessuna attività nella quale non ci fosse al centro la rappresentazione; un progetto, un quadro a olio, una decorazione parietale, una 'ricostruzione', sempre un 'disegno'. Anche le volte che, da piccolo (io), mi portava con sé nel fine settimana con qualche amico, si andava facilmente a pranzo in una trattoria con le tovaglie di carta; e giù a disegnare a sognare a segnare. La produzione di immagini del suo cervello era continua, e il più delle volte veniva immediatamente 'significata' dalla mano, che con una matita su di un foglio di carta, ne rendeva visione in una operazione ermeneutica.

E ciò che lo entusiasmava di più del disegno era proprio questa incredibile capacità di rendere visibile ciò che non lo è; un'idea, un pensiero, un monumento distrutto, un monumento che non è mai esistito.

E quindi gli album illustrati sono pieni di disegni, progetti di cose pensate e di case realizzate, ma classiche foto di amici e parenti, e foto di viaggi. Ah sì, ogni anno, cascasse il mondo, uno o due viaggi con Attilia se li doveva fare: il giro del mondo in 80 ... anni.

Nel primo album inizia l'autobiografia illustrata con il capitolo II mondo di Carlo, secondo nome di battesimo di Alberto e nome comunemente utilizzato da tutti. La vita dalla nascita al matrimonio con Attilia. In una pagina vediamo due ricostruzioni della facciata di San Pietro sopra alle quali è appuntato "I945-46-48", e a fianco "Primi studi per S. P[ietro] / per Matt[h]iae senior". Alberto si riferisce a Guglielmo Matthiae, per il quale aveva evidentemente elaborato le ricostruzioni dei progetti del Maderno e del Bernini, che però non furono evidentemente pubblicati e restarono nel cassetto per decenni.

Negli anni Settanta l'attività editoriale di Alberto diviene sempre più centrale.

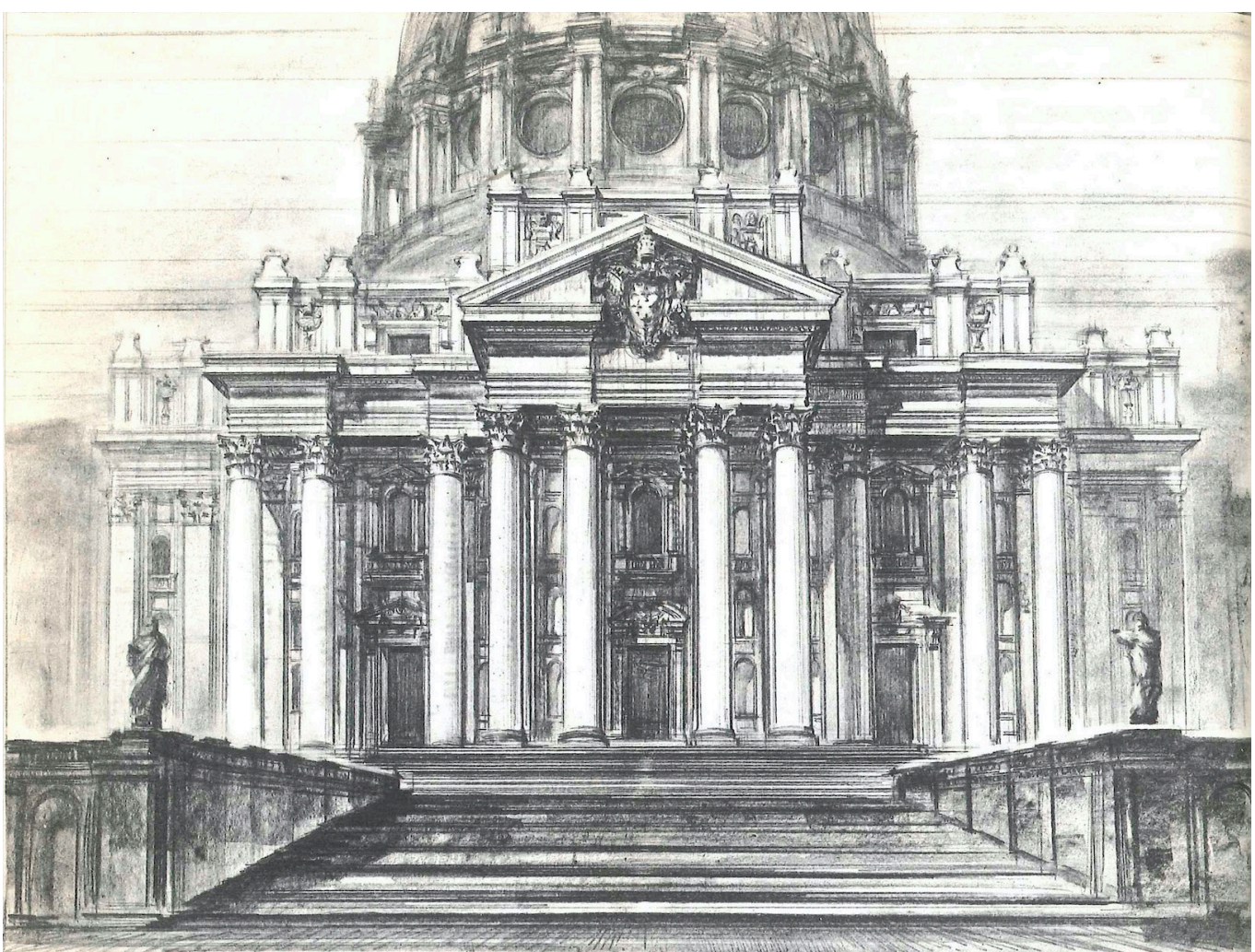


Nel 1977 fu pubblicato un articolo nella rivista Istruzione Tecnica [Carpiceci 1977] dove apparve una prima ricostruzione della facciata progettata da Michelangelo con il nartece colonnato e un pronao centrale tetrastilo (fig. 6). Alberto spiegava come il Buonarroti arriva alla Fabbrica alla fine del periodo iniziato da Bramante e sviluppatosi sino ai Sangallo. II nuovo modello ligneo in poco tempo viene presentato all'approvazione del papa e così si "ritirava San Pietro a minor forma, ma sì bene a maggior grandezza" [Vasari 20 I2].

A tre anni di distanza, Alberto pubblica nella rinnovata rivista dell'Istruzione Tecnica [Carpiceci 1980] uno studio approfondito sulla facciata del tempio cristiano da Bramante a Bernini. In una riassuntiva illustrazione vengono rappresentate alcune facciate in cui sono presenti $\mathrm{i}$ campanili laterali (fig. 7). Bramante, Raffaello, Antonio da Sangallo, Cigoli, Maderno e Bernini; tutti antagonisti dell'idea michelangiolesca nella quale l'unica emergenza dall'attico doveva essere la copertura della tomba di Pietro, la cupola.

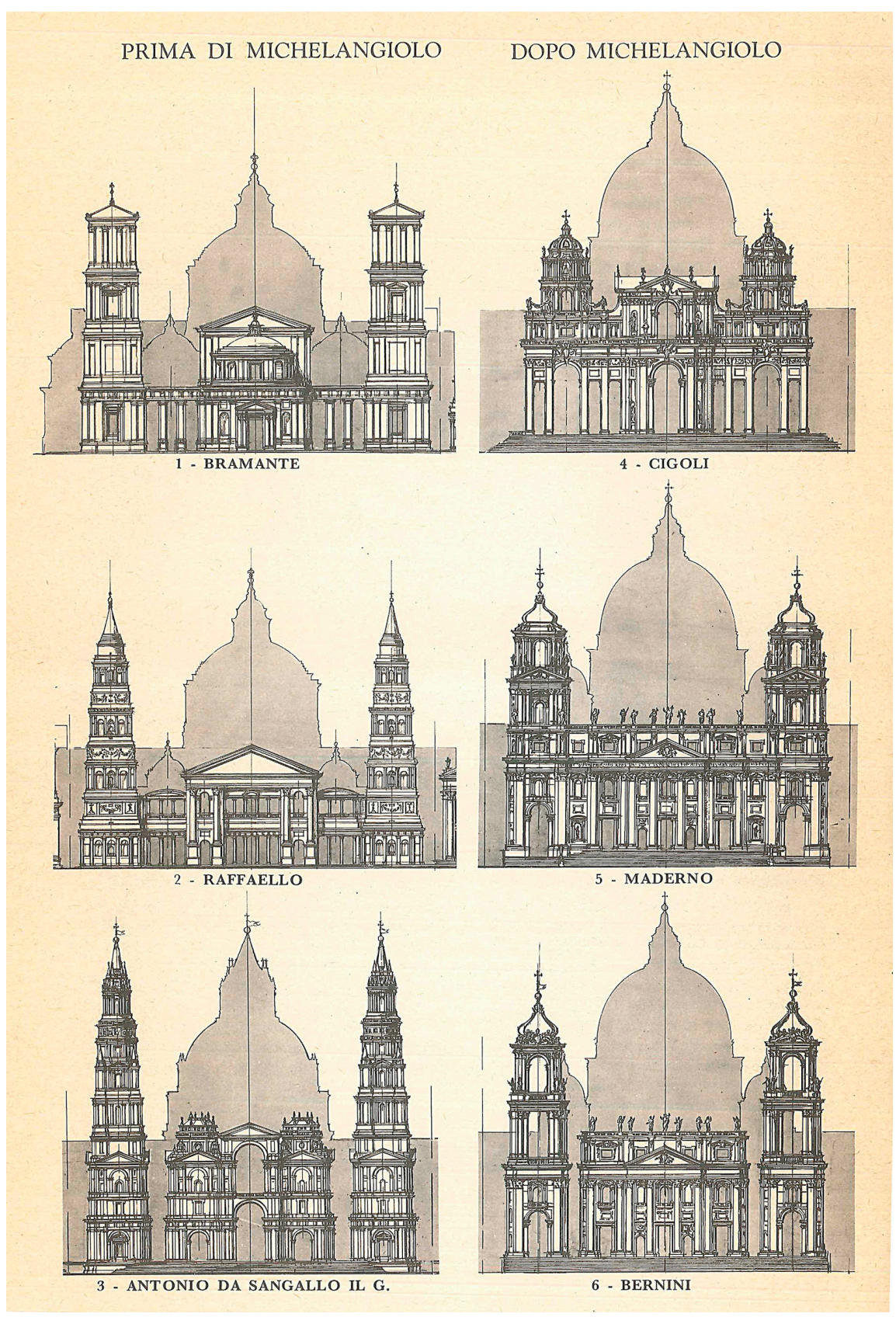




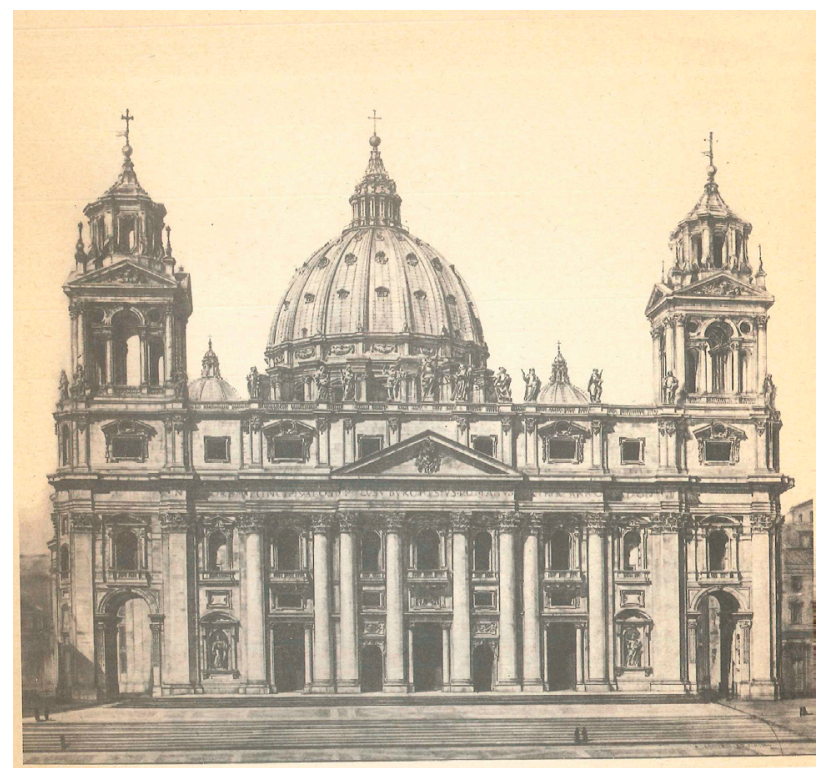

A pagina 14 | Alberto finalmente pubblica la prima ricostruzione eseguita per Matthiae intorno al 1946, il progetto di Maderno (fig. 8). Qui il trentenne Carpiceci aveva preso una fotografia della facciata e l'aveva riprodotta con grande precisione; e su di essa aveva poi aggiunto i campanili presenti nel progetto seicentesco e non più realizzati (fig. 9).

Con il prolungamento longitudinale la chiesa michelangiolesca veniva a sconvolgere non poco l'impostazione iniziale basata sulla centralità della cupola e l'annullamento di qualsiasi elemento che potesse interferire nel concetto morfologico progettuale.

Alle pagine |45-I46 e |47-I48 dello stesso articolo troviamo due ricostruzioni di due progetti Berniniani sempre per la medesima facciata (figg. I0, I I). II primo è l'altro disegno dell'album dei ricordi, mentre il secondo fa certamente parte dello stesso lavoro ma probabilmente Alberto non aveva ritrovato la fotografia relativa per inserirla tra i ricordi.

Nella prima ricostruzione Bernini isola la facciata alla sola navata centrale, staccando completamente i campanili. Nella seconda ricostruzione, secondo Alberto, Bernini suggerisce di eliminare anche l'attico dal pronao, retrocedendo quindi tutta la facciata. In questa maniera si sarebbe recuperata una maggiore visibilità della cupola, recuperando così la volontà morfologica del Buonarroti.

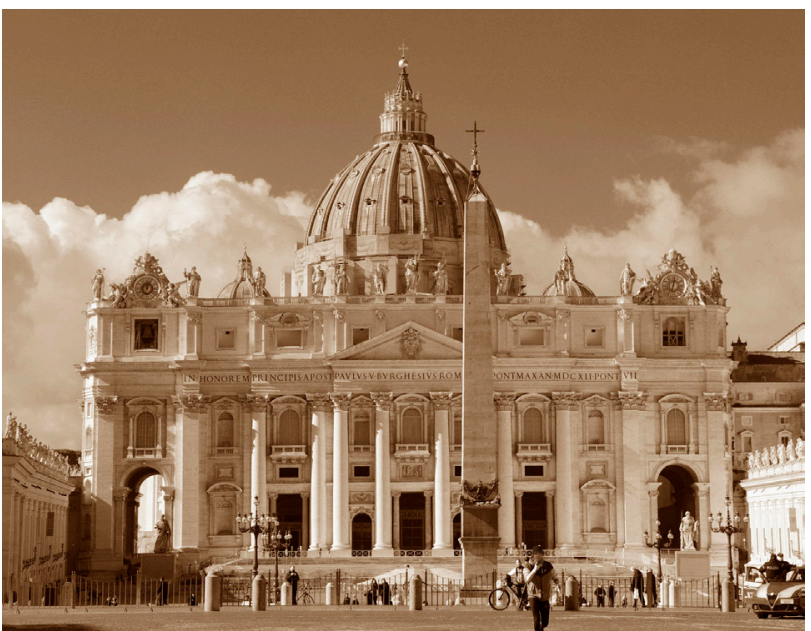


Fig. 10. Alberto Carpiceci, Ricostruzione del progetto

con campanili indipendent. 1946.

Fig. I I. Alberto Carpiceci, Ricostruzione del progetto di Gian Lorenzo Bernini con campanili indipendent e attico retrocesso, 1946.

Fig. 12. Alberto Carpiceci Ricostruzione dell'ultimo progetto michelangiolesco per la facciata di San Pietro, 1983.
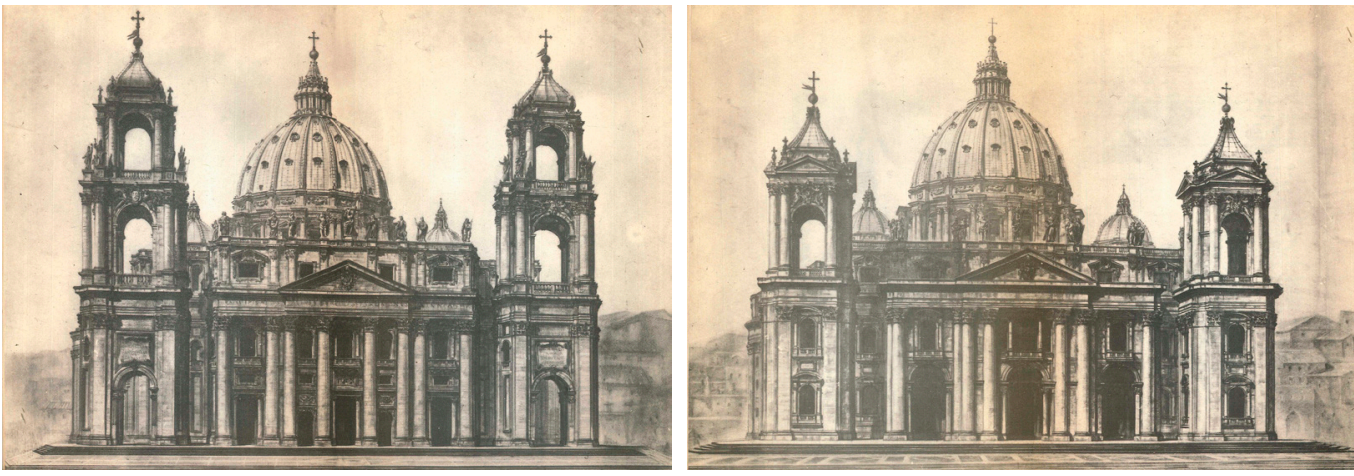

Ma, dice Alberto, "con il colonnato Bernini tocca il massimo trionfo. Forse in questa opera grandiosa dimentica volentieri la 'facciata ideale' e i campanili per San Pietro che erano stati la 'tragedia' maggiore della sua vita" [Carpiceci 1980].

Nel 1983, grazie alla stretta collaborazione con l'editore Bonechi di Firenze, Alberto diede alle stampe una imponente monografia riguardante l'intera storia della basilica vaticana dall'epoca costantiniana della sua prima edificazione sino ai giorni nostri [Carpiceci 1983]. Il tema della facciata accompagna, chiaramente, tutta l'opera e il volume è pieno di ricostruzioni ormai arricchite del colore, che le rende ancor più reali, in una sorta di realtà virtuale ante litteram.

Alla pagina 219 abbiamo la ricostruzione a colori del progetto michelangiolesco (fig. 12). II disegno ricalca la stessa base prospettica di quello del '77, ma mentre allora aveva rappresentato la cupola con gli occhialoni come nel primo progetto del Buonarroti, qui vengono disegnati i finestroni in accordo con la cupola realizzata.

II rinnovamento cromatico di Alberto si ferma però per le ricostruzioni del 1946. || sacro rispetto dell'Alberto trentenne pieno di forza ed entusiasmo frena la capacità di rappresentazione dell'uomo visionario: ciò che era è [I].

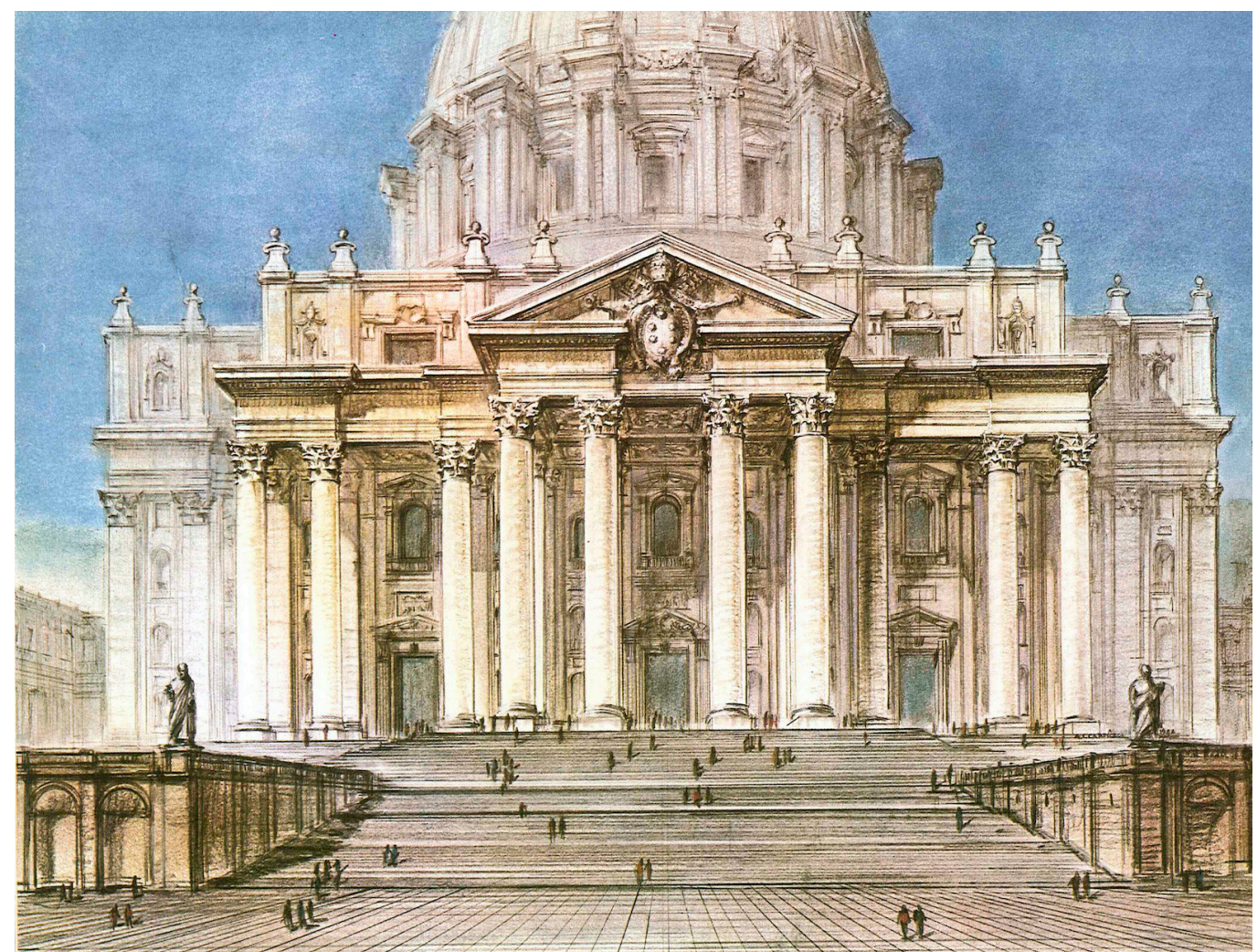




\section{Note}

[I] II presente contributo è stato elaborato dagli autori in completa collaborazione, in particolare Antonio Schiavo ha curato il paragrafo su Luigi Moretti e Marco Carpiceci quello su Alberto Carpiceci.

\section{Riferimenti bibliografici}

AA.W. (1926). Annuario della R. Scuola di Architettura di Roma. AA 1925-26, 1926-27. Roma: tip. Pallotta.

Carpiceci A.C. ( 1 977). Michelangelo sconosciuto. II tempio massimo. In Istruzione Tecnica, n. 5I, pp. 96- 109.

Carpiceci A.C. (1980). Gian Lorenzo Bernini e la Fabbrica di San Pietro. In Istruzione tecnica e professionale, n. 62-63, pp. I27-I 50.

Carpiceci A.C. (198I). Roma antica: oggi e com'era 2000 anni fa. Firenze: Bonechi.

Carpiceci A.C. (1983). La Fabbrica di San Pietro, venti secoli di storia e progetti. Firenze: Bonechi.

Carpiceci A.C. (199I). Progetti di Michelangiolo per la Basilica Vaticana. In Bollettino d'arte, n. 68-69, pp. 23 - I06.

Dal Maso L.B. (1975). La Roma dei papi. San Pietro e il Vaticano. Firenze: Bonechi.

Fasolo V. (1924). La cappella Sforza di Michelangelo. In Architettura e Arti Decorative, fasc. X.

Fasolo V. (1927). Disegni architettonici di Michelangelo. In Architettura e Arti Decorative, fasc. IX-X.

Fasolo V. (1954). Guida metodica per lo studio della storia dell'architettura. Roma: Edizioni dell'Ateneo.

Fasolo V. (1958). Analisi grafica dei valori architettonici. Lezioni del prof. Vincenzo Fasolo. Roma: Università di Roma, Facoltà di Architettura, Istituto di Storia dell'architettura.

Fasolo M., Mancini M. F. (20I4). Visioni architettoniche urbane nei disegni di Vincenzo Fasolo. In Disegnare. Idee immagini, a. XXIV, n. 48, pp. 56-67.

Frey D. (1926). Architettura barocca. Roma-Milano: Soc. Ed. Arte Illustrata.

Giovannoni G. (1 922). Tra la cupola di Bramante e quella di Michelangelo. In Architettura e Arti Decorative, fasc. V.

Giovannoni G. (a cura di). (1932). La Scuola di Architettura di Roma. Roma: Cremonese Editore.

Hempel E. (1926). Francesco Borromini. Roma-Milano: Soc. Ed. Arte Illustrata.

Magni G. (| 9 | | - |3). Il barocco a Roma nell'architettura e nella scultura decorativa. Torino: C. Crudo \& C.

Mariani V. (1943). Michelangelo e la facciata di San Pietro. Roma: Fratelli Palombi - Editori.

Moretti L. (1927). Canovaccio per un saggio sull'architettura di Michelangelo e del Borromino e su quella barocca in genere; e intorno alla natura dell'architettura e alle possibilità di una nuova critica architettonica. Roma: Archivio Moretti Magnifico.

Moretti L. (1957). Forma come struttura. In Bucci F., Mulazzani M. (a cura di). (2000). Luigi Moretti. Opere e scritti, pp. I82-I84. Milano: Electa.

Moretti L. (1964). Le strutture ideali della architettura di Michelangelo e dei barocchi. In Bucci F., Mulazzani M. (a cura di). (2000). Luigi Moretti. Opere e scritti, pp. 192- 195. Milano: Electa.

Muratore G. (7 dicembre 20 I I). Vincenzo Fasolo. I/ vero maestro di tutti i romani. <https://archiwatch.it/20 I I/I 2/07/vincenzonedawagnerasanluca-lingegnereartista-maestroditutti/> (consultato il 25 gennaio 2021).

Ricci C. (1912). Architettura barocca in Italia. Stuttgard: Julius Hoffmann Editore.

Rostagni C. (2006). Moretti, Michelangelo e il barocco. In Casabella, a. LXX, n. 6, pp. 8 I-85.

Vasari G. (20I2). Le vite.Traduzione in italiano contemporaneo di Marco Cavalli.Vicenza Colla Editore. [Prima Ed. Le vite de' più eccellenti pittori, scultori e architettori. I550].

\section{Autori}

Marco Carpiceci, Sapienza Università di Roma, marco.carpiceci@uniromal .it

Antonio Schiavo, Sapienza Università di Roma, antonio.schiavo@uniromal.it

Per citare questo capitolo: Carpiceci Marco, Schiavo Antonio (2021). La facciata della Basilica di San Pietro: connessioni tra Luigi Moretti e Alberto Carpiceci/The facade of St. Peter's Basilica: connections between Luigi Moretti and Alberto Carpiceci. In Arena A., Arena M., Mediati D., Raffa P. (a cura di). Connettere. Linguaggi Distanze Tecnologie. Atti del $42^{\circ}$ Convegno Internazionale dei Docenti delle Discipline della Rappresentazione/ Connecting. Languages Distances Technologies. Proceedings of the $42^{\text {th }}$ International Conference of Representation Disciplines Teachers. Milano: FrancoAngeli, pp. 353-370. 


\title{
The Façade of St. Peter's Basilica: Connections between Luigi Moretti and Alberto Carpiceci
}

\author{
Marco Carpiceci \\ Antonio Schiavo
}

\section{Abstract}

The topic of the 'connection' suggested a comparison between two architects, both members of the Roman School of the early twentieth century, and both, not only ascribable to the category of 'integral architect', but also 'architects-humanist', two profiles with a high cultural level, not only in the area of architecture: Luigi Moretti (1906-1973) and Alberto Carpiceci (1916-2007).

The aim of this essay is to connect two different methods of study, in the subjects as the graphic analysis and the history of representation, concerning the design of the façade of St. Peter's Basilica in Rome by Michelangelo Buonarroti (1475- 1564), in terms of designing and construction.

One of the biggest contacts between these two architects is the constant research about the figure of Michelangelo as architect, research suggested in both cases by the academic teaching of Vincenzo Fasolo (1 885-1969), professor of History and Styles at the Superior School of Architecture in Rome.

Keywords

Michelangelo Buonarroti, St. Peter's Basilica, history of representation, graphic analysis, history of architecture.

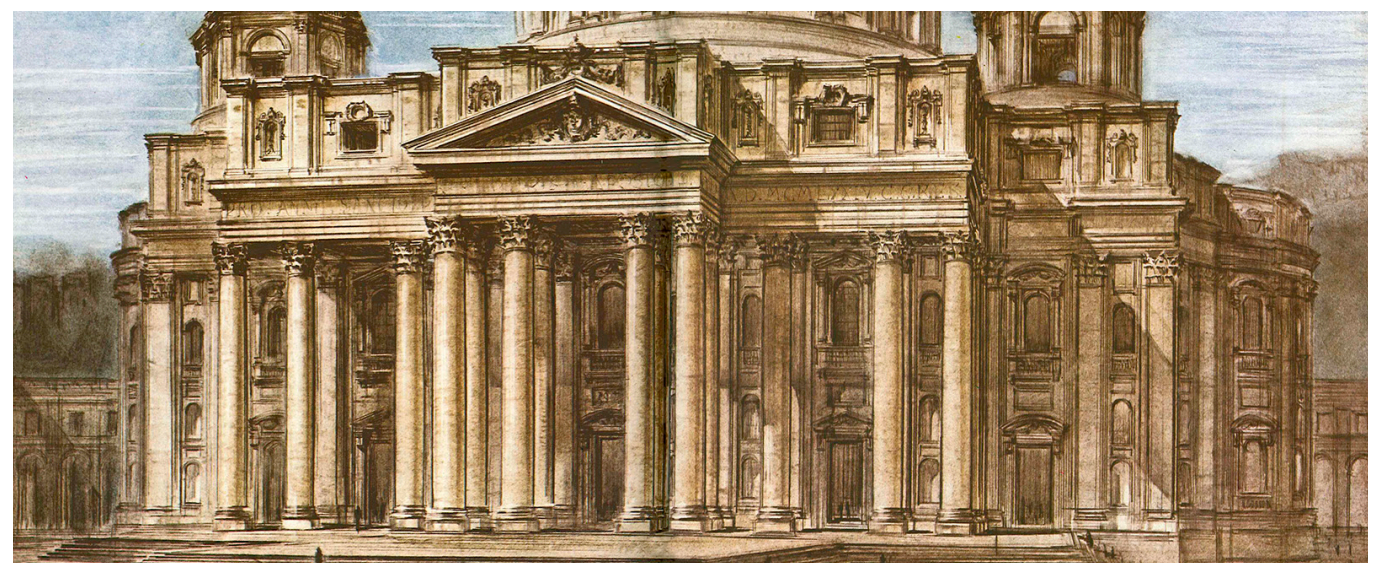




\section{Introduction}

The course of Vincenzo Fasolo was a crossroad between theorical and technical subjects, a true reflection of the spirit of the School. The study of the ancient monuments, seen as a fundamental approach to the modern designing, was explored with the practice of the drawing and with the ability of a 'four-dimensions' interpretation of architecture, leading in a 'temporal perspective' of the building, which was dissected, analyzing not only the decorative apparatus but, more specifically, the 'architectural values' and the 'ideal schemes'. Fasolo was not only the master of Moretti and Carpiceci, but also of other important profiles as Mario Ridolfi (I904-1984), Bruno Zevi (1918-2000), Luigi Pellegrin (I925-200 I). From Fasolo, as stated by Giorgio Muratore (1946-2017), was born the 'roman modern space' [Muratore $20 \mathrm{I} \mathrm{I}$; he was able to synthesize the lessons not only of Michelangelo and the baroque, but also of Otto Wagner (184|-19|8) and his Moderne Architektur.

During his lessons were explained the "general data concerning the evolution of the styles and their relationships with needs and various means, with a technical-stylistic character, with a special reference to the history of architecture, considering deeply the building organism of the monuments and the evolutions of architectural forms" [AA.VV. 1926]. Giving "not only general conditions but also drawings of schemes, a more direct and effective study of the masses and the volumes" [Giovannoni 1932].

Everything comes to life with the use of the projective geometry, with the particular rotations of axonometries which allow to understand the most intimate secrets and, in the meanwhile, founding, of the architecture, even with the studies of the "geometrical values" [Fasolo 1954].

Fig. I. Conservatori Palace, ideal scheme of the façade of Michelangelo, preparatory sketch for the $3^{\text {rd }}$ board (Moretti, the 3 rd
1927).

Fig. 2. Conservatori

Palace, building organism of the palace, preparator sketch for the $4^{\text {th }}$ board (Moretti, 1927)
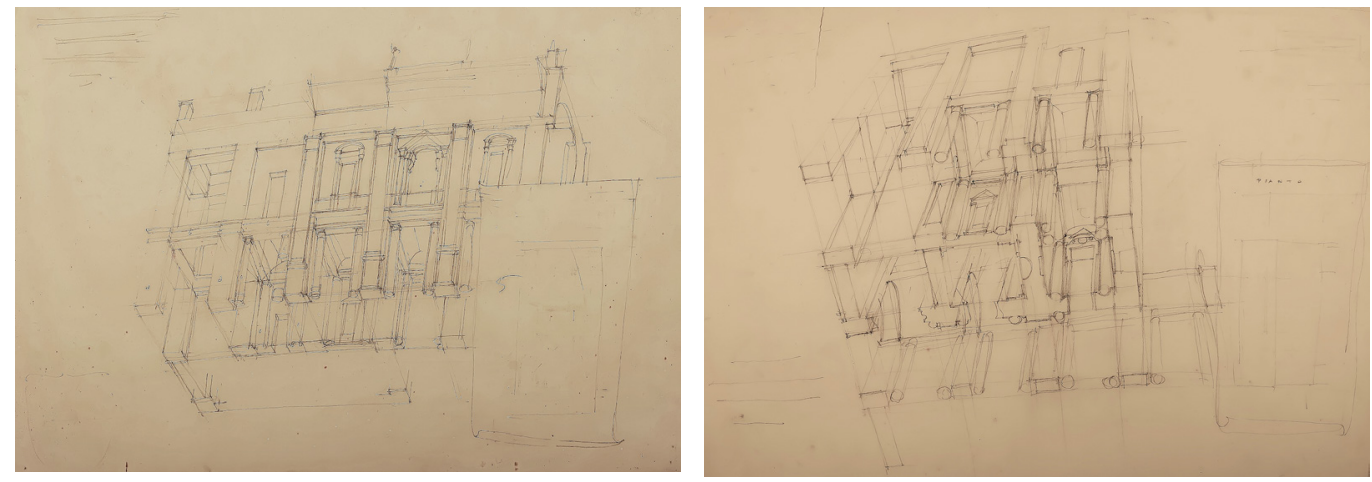

\section{Luigi Moretti: the 'constructive feeling' of Michelangelo}

In the October of 1927 Moretti, for the course of Fasolo, submitted a research concerning the architecture of Michelangelo and baroque, the Canovaccio [Moretti 1927], a work with drawings and handwritten essays, split between a theoretical part and a practical one, with graphic analysis. This document is fundamental in order to understand his cultural and graphical formation in relation to his teacher. The analysis of the work of Michelangelo is the core of this research, which will be taken up and built on in 1964, during a conference in the San Luca Academia in Rome [Moretti 1964].

The figure of Michelangelo as an architect is rediscovered in Rome during the "IOs and for all the '20s, right through the cultural activities not only of Fasolo, but also of Gustavo Giovannoni (I 873- 1947), Giulio Magni (I 859-1930), Corrado Ricci (I858- 1934). However, Moretti seems to take a parallel path compared to his teachers, latching on his studies to some researchers of Vienna at the beginning of the century, especially to Alois Riegl ( 1858 1905), Eberhard Hempel (1886-1967) and Dagobert Frey (I883-1962). 
In the Canovaccio Moretti introduces his personal idea about the essence of architecture based on the "constructive feeling as particular nature of the animus of the architect as such", feeling aimed at the highlighting of the fundamental and ideal elements, from which arises the concept of the construction as "final reality to which the constructive processes give rise" [Moretti 1927]. All these principles are explained in the graphics, specially produced by Moretti, still as a student, starting from theoretical concepts, life drawing and surveys.

In the sheets III and IV (figs. I , 2) Moretti analyses the Conservatori Palace, an architecture with an ideal scheme which shows more similarities with the design of St. Peter's façade. In these two different axonometries from the bottom, drawn with pencil and Indian ink on yellow paper, there is a clear distinction of the training elements of the Michelangelo's work: a frame made of pillars that branch off over the full heigh with their related lintels at the first storey and in the top; closure of the intercolumns on the façade at the first storey and consequent installation of two columns at the ground floor; building at the first storey of openings on the walls for the windows, with their related stone arches which are shown outside as curved tympanums, and supported by a pair of little columns as well; lastly the presence of an important ledge makes a reinforcement with pilaster strips indispensable.

These drawings, read from the left to the right, represent the history of the conception, or the ideal process, of the building, which is repeated not only on the length of the façade, but also on the sides; in this case "the incarnation of the constructive feeling in the construction and, consequently, the identity between ideal process of formation and building process, is almost complete" [Moretti 1927]. Here there's the birth of the consequent comparison with the huge architectures of the imperial Rome, "which are also models, thanks to their perfect architectural conception, of possibility of execution and rationality in the building site, because the great roman architect, in his ideal process, was really already building" [Moretti 1927].

Very interesting a statement of Moretti: how the study reveals a personal reasoning of him, filtered through the Fasolo's teachings: "I state that what I'm going to say, was born spontaneously in my mind by the innocent and admired observation of the building" [Moretti 1927], and in this very building -Conservatori Palace- he found the "most vivid
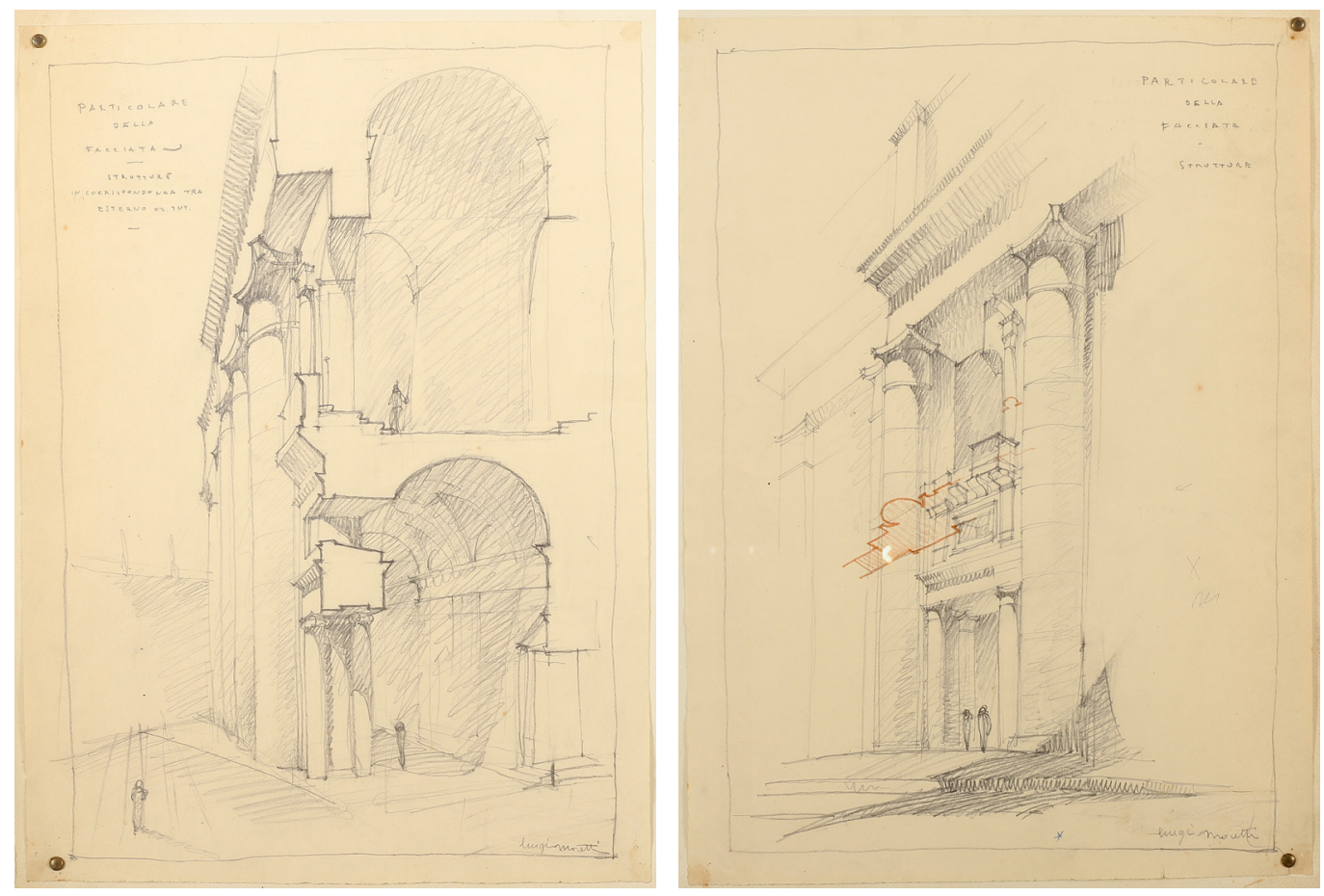
example" of a "very strict 'kingdom' as intellective representation of logically possible structures" [Moretti 1957].

All these aspects consequently lead to the analysis of St. Peter's façade. As is known the Michelangelo's architectural concept was noticeably altered by Carlo Maderno (I5561629), however, the graphic analysis of Moretti shows that the constructive feeling of the ideal binary structure of the Michelangelo's design was preserved, synthesizing, in the new façade, the original concept of the Florentine architect with the style of the southern façade of the Basilica.

Moretti realizes a perspective cutaway (fig. 3) showing a part of the constructive scheme of the façade, highlighting the section line: a suggestive drawing, but very simple, which clarifies his ideas. This is followed by another perspective (fig. 4) in which an intercolumn is highlighted, and its tridimensionality is emphasized by chiaroscuro, realized with the cross-hatching technique. Lastly an axonometric cutaway (fig. 5) in which the "plastic-constructive feeling' is pointed out, as Moretti used to call it, following the example of the Conservatori Palace.

As a corollary to the graphic analysis Moretti states that "for the Basilica is imagined a pronaos with the same width and height, and characterized by a classical model with columns and architraves"; subsequently "the pronaos is split in height, via a secondary structure, independent of the principal one (the columns), by a barrel vault, with its shutter corresponding to the frame of the façade" [Moretti 1927].

Resuming his early studies, in 1964 he investigates the matter stating that "who inherited the concept of the porched façade of the Michelangelo's design, inherited, in the meanwhile, the manner of its translation, building it up for new needs. The structure of Michelangelo is conceptually intact: between the powerful columns, vehement, were built, by the humans for the humans, but leaving free and intact the column, free structures which connect doors, balconies, windows. In an ideally independent construction, which shattered Michelangelo's space against Michelangelo himself, but in his way" [Moretti 1964].

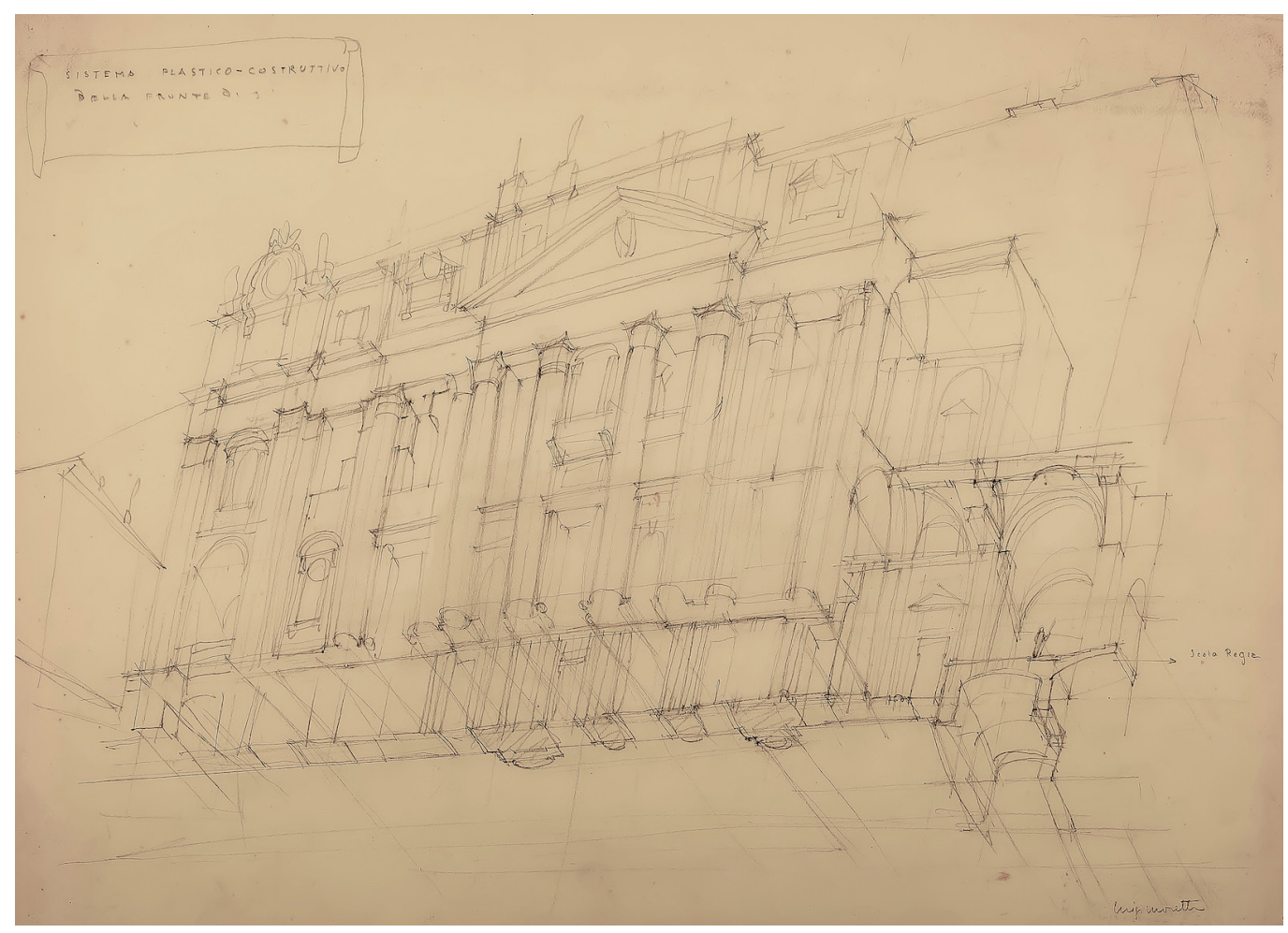




\section{Alberto and his visions of the St. Peter's façade}

During the last years Alberto Carpiceci used to relive his existence making illustrated albums concerning the salient moments of his life; or rater, all those moments which he remembered how such, and which he decided to testify.

'Representation' has always been the fundamental structure of his existence. For sure he was a talker and a fanciful but, for every thought, for every fantasy, there had to be a drawing. I don't remember any activities without the representation; a design, an oil painting, a wall decoration, a 'reconstruction', always a 'drawing'. Even in the times when he used to take me along, when I was a child, at the weekend with some friend of mine, easily we used to go out for lunch in a trattoria with paper tablecloths; he used to start sketching, drawing, and dreaming. The production of images in his brain was never ending and, most of the time, those images were signified by the hand, which with a lead holder on a sheet of paper, used to make that vision a hermeneutic operation.

And what used to make him more enthusiastic of the drawing was right this incredible ability to make visible what it's not; an idea, a though, a destroyed moment, a moment never existed.

So, these illustrated albums are full of drawings, designs of thought things and of built houses, and even fill of classical photos with friends and relatives, and travel photos as well. Oh yes, every year, no matter what, he had to take a trip with Attilia: Around the World in 80 ... years. In the first album begins the illustrated autobiography with the chapter called II mondo di Carlo [Carlo's world], middle name of Alberto, and name commonly used by everyone. The life from the birth to the marriage with Attilia. In a page we can see two reconstructions of the St. Peter's façade with the caption "I945-46-48" and "Primi studi per S. P[ietro] / per Matt[h]iae senior". Alberto refers to Guglielmo Matthiae, for whom evidently made the reconstructions of the designs of Maderno and Bernini, which obviously were not published and remained put away for decades.

In the Seventies the editorial activity of Alberto become more and more centrale.

Fig. 6. Reconstruction of the possible proposition by Michelangelo for the St. Peter's façade (Alberto Carpiceci, 1977).

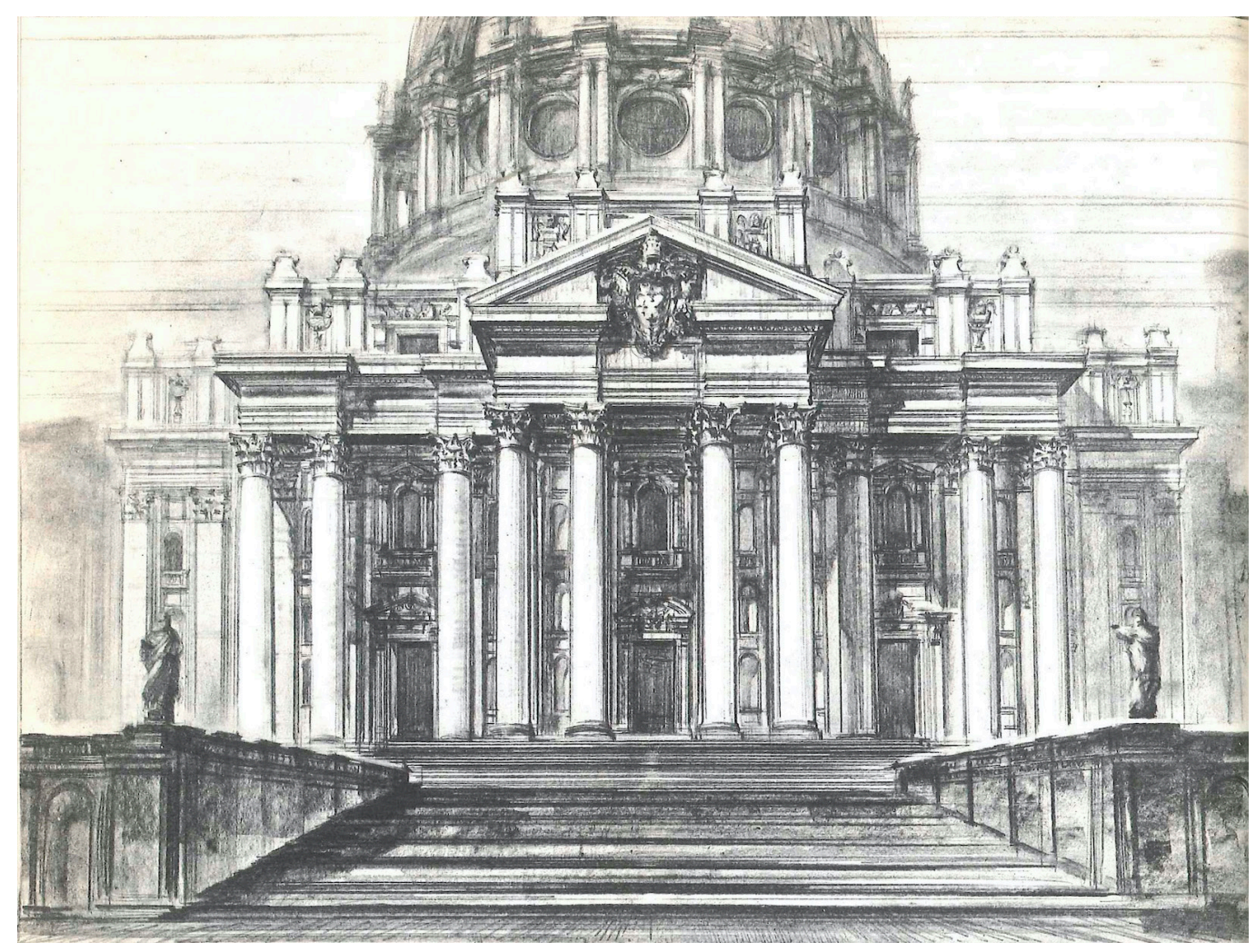


In 1977 an article was published in a magazine called Istruzione Tecnica [Carpiceci 1977] where the first reconstruction of the façade concepted by Michelangelo appeared, with the columned narthex and a central tetrastyle pronaos (fig. 6). Alberto explains how Buonarroti arrived at the Fabbrica at the end of the phase begun by Bramante and developed until the two Sangallo. The new wooden model was presented for the approval of the pope with these words: "ritirava San Pietro a minor forma, ma sì bene a maggior grandezza" [Vasari 20I2].

After three years Alberto publishes in the renovate magazine Istruzione Tecnica [Carpiceci 1980] an in-depth study of the façade of the Christian temple from Bramante to Bernini. In a summary illustration are represented some façades with the lateral bell towers (fig. 7). Bramante, Raffaello, Antonio da Sangallo, Cigoli, Maderno and Bernini; everybody against the idea of Michelangelo, in which the one vertical element on the attic had to be the covering of the St. Peter's tomb, the dome.

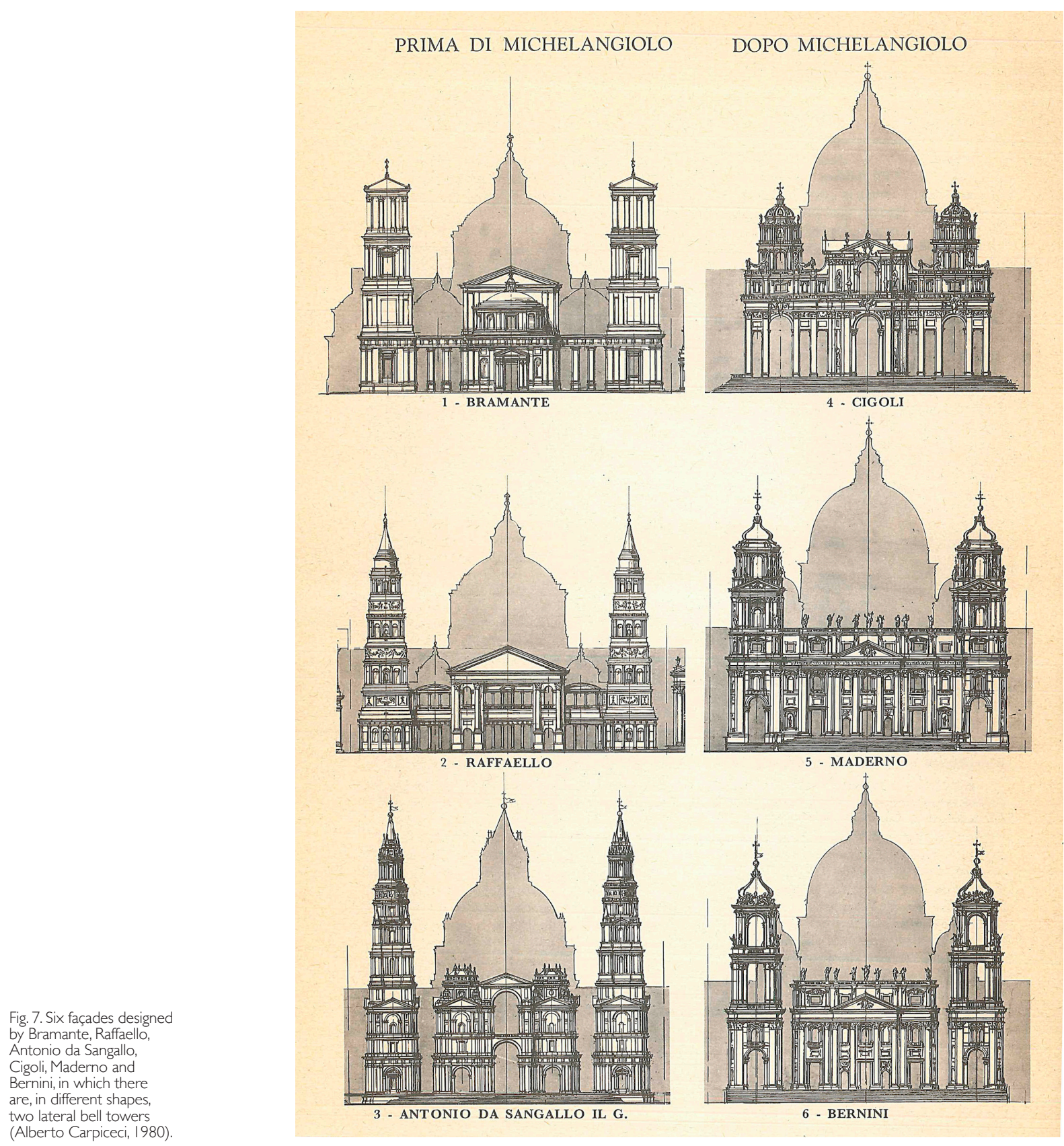


Fig. 8. Reconstruction of the proposal by Carlo Maderno with the planned lateral bell towers (Alberto Carpiceci,

1946).

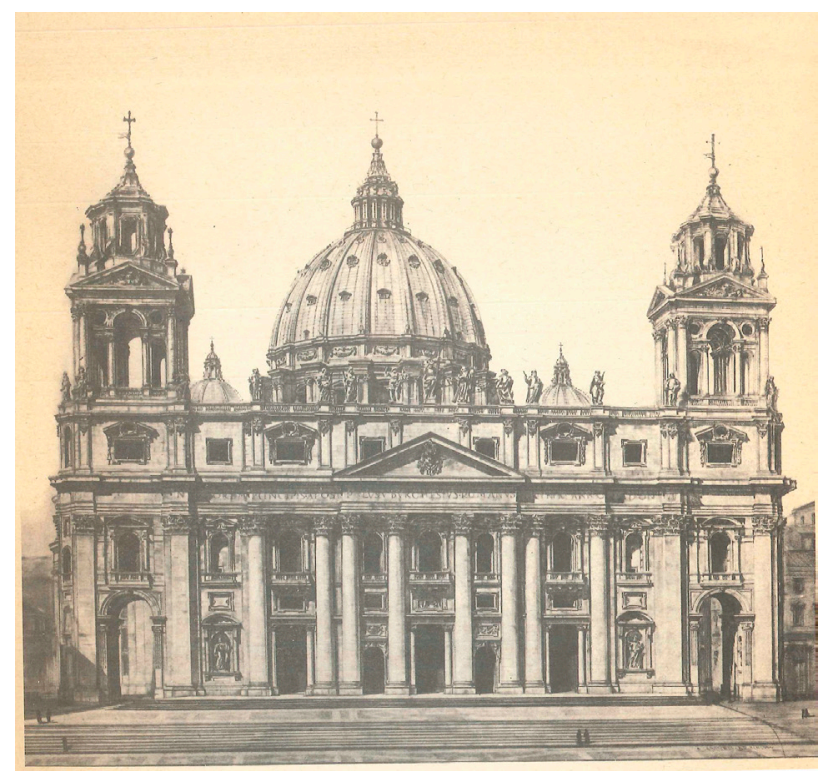

On page |4| Alberto finally publishes the first reconstruction made for Matthiae back in 1946, the concept of Carlo Maderno (fig. 8). Here the thirty-year-old Alberto took a photo of the façade which was perfectly reproduced; on this photo he added later the bell towers, referred to the seventeenth-century design and never built (fig. 9).

The longitudinal extension of the Michelangelo's concept varied significantly from the original setting, based on the centrality of the dome with any cancellation of other elements that could interfere the morphological concept.

On pages |45-146 and |47- |48, in the same article, there are two reconstructions of two designs by Bernini, both for the same façade (figs. I0, I I). The first one is the other drawing from the scrapbook, while the second is certainly part of the same work but it's not present in the scrapbook.

In the first reconstruction Bernini isolate isolates the façade only in correspondence with the central nave, detaching completely the bell towers. In the second reconstruction, in Alberto's opinion, Bernini suggests the cancellation of the attic from the pronaos, receding all the façade. In this way a greater visibility of the dome would be recovered, recovering the morphological will of Buonarroti.

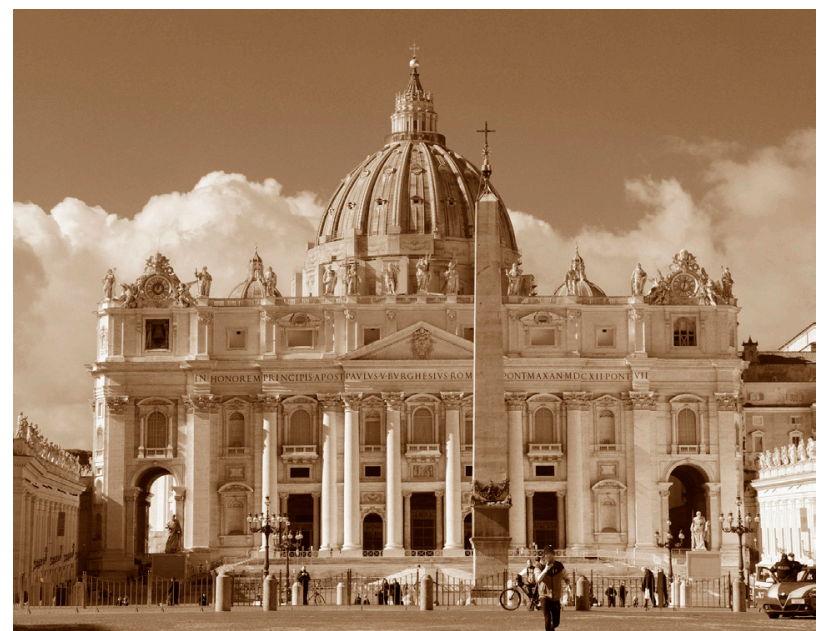


Fig. 10. Reconstruction of the proposal by Gian Lorenzo Bernini with independent bell towers (Alberto Carpiceci, 946).

Fig. I I. Reconstruction of the proposal by Gian of the proposal by Gith independent bell towers and the attic moved and the attic moved Carpiceci, 1946).
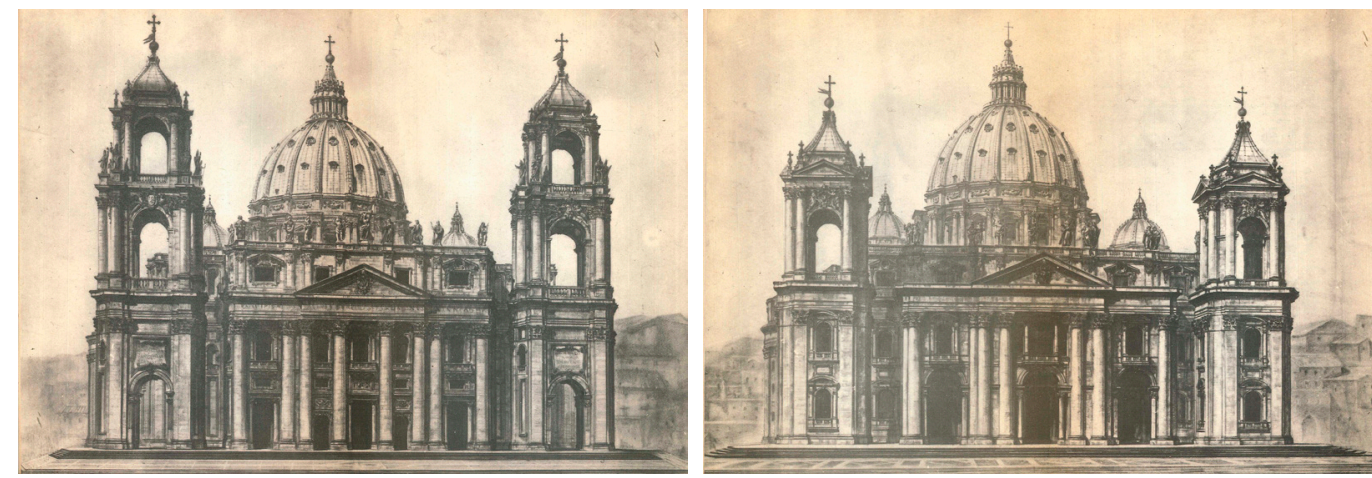

Says Alberto: "with the colonnade Bernini reaches the greatest success. Perhaps in this great work gladly forgets the 'ideal façade' and the bell tower for the Basilica which would have been the greatest tragedy of his whole life" [Carpiceci 1980].

In the 1983, thanks to the close collaboration with the publisher Bonechi from Florence, Alberto published an important monography concerning the whole history of the Vatican Basilica, from the Constantine period of his first construction up to the present days [Carpiceci 1983].

The topic of the façade clearly leads the whole work, and the book is full of reconstructions now enriched by the color, which makes them even more real, in a sort of virtual reality ante litteram. On page 219 we can see the color reconstruction of the Michelangelo's design (fig. 12). The drawing retraces the same base of the perspective from the ' 77 , but while there he represented the dome with the round windows, according to the first Michelangelo's concept, now the squared windows are drowned, as we can see in the built version.

The chromatic renovation of Alberto stops with the ' 46 's reconstructions. The holy respect to the thirty-year-old Alberto, full of strength and enthusiasm, holds the ability of representation of the visionary man: what it was, is [I].

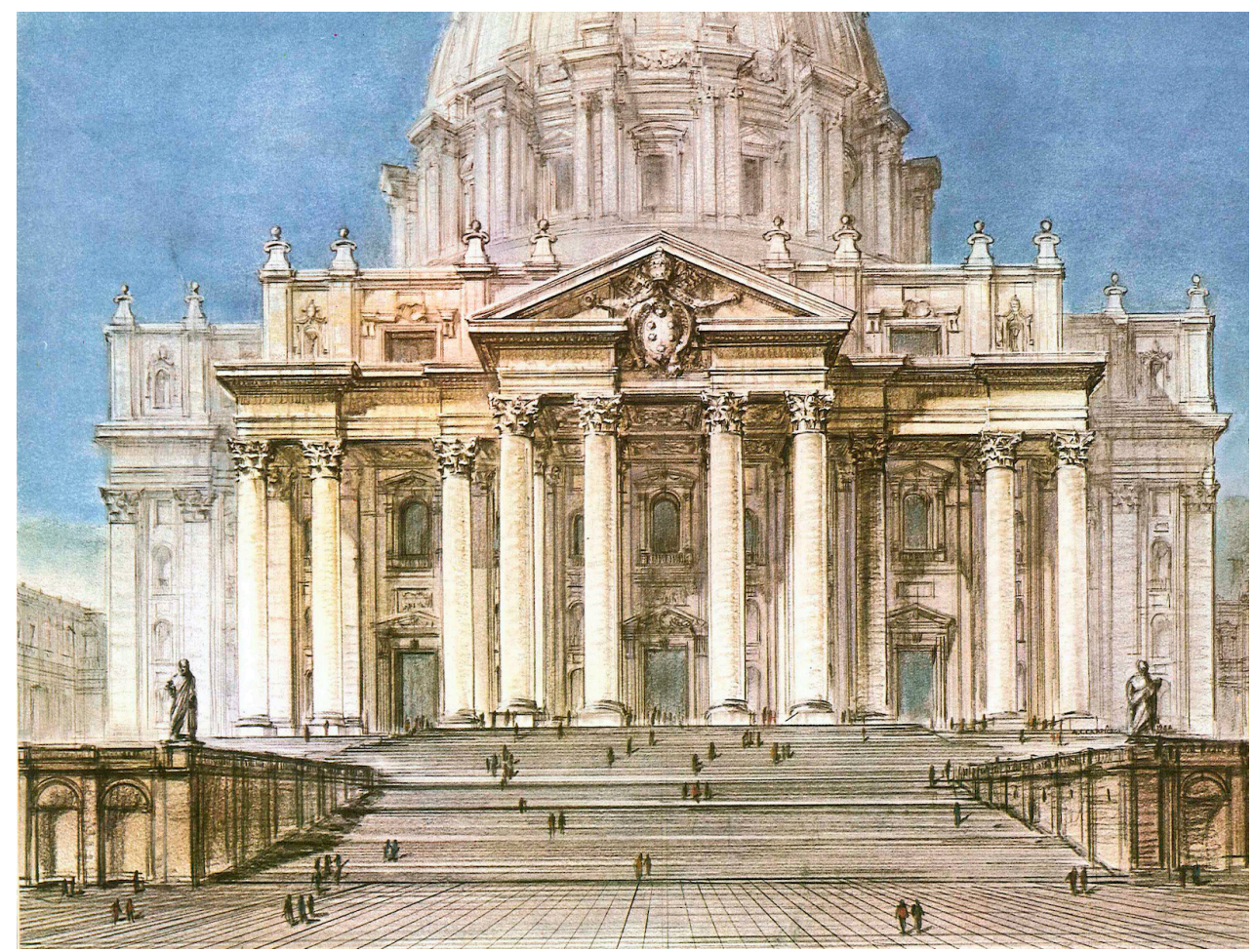




\section{Notes}

[I] This paper was written by the authors with a full cooperation; in particular, Antonio Schiavo edited the paragraph about Luigi Moretti, while Marco Carpiceci wrote the one about Alberto Carpiceci.

\section{References}

AA.W. (1926). Annuario della R. Scuola di Architettura di Roma.AA 1925-26, 1926-27. Roma: tip. Pallotta.

Carpiceci A.C. ( 1 977). Michelangelo sconosciuto. II tempio massimo. In Istruzione Tecnica, n. 5I, pp. 96- 109.

Carpiceci A.C. (1980). Gian Lorenzo Bernini e la Fabbrica di San Pietro. In Istruzione tecnica e professionale, n. 62-63, pp. I 27 - I 50.

Carpiceci A.C. (198I). Roma antica: oggi e com'era 2000 anni fa. Firenze: Bonechi.

Carpiceci A.C. ( 1983). La Fabbrica di San Pietro, venti secoli di storia e progetti. Firenze: Bonechi.

Carpiceci A.C. (199I). Progetti di Michelangiolo per la Basilica Vaticana. In Bollettino d'arte, n. 68-69, pp. 23 - 106.

Dal Maso L.B. (1975). La Roma dei papi. San Pietro e il Vaticano. Firenze: Bonechi.

Fasolo V. (1924). La cappella Sforza di Michelangelo. In Architettura e Arti Decorative, fasc. X.

Fasolo V. (1927). Disegni architettonici di Michelangelo. In Architettura e Arti Decorative, fasc. IX-X.

Fasolo V. (1954). Guida metodica per lo studio della storia dell'architettura. Roma: Edizioni dell'Ateneo.

Fasolo V. (1958). Analisi grafica dei valori architettonici. Lezioni del prof. Vincenzo Fasolo. Roma: Università di Roma, Facoltà di Architettura, Istituto di Storia dell'architettura.

Fasolo M., Mancini M. F. (20I4). Visioni architettoniche urbane nei disegni di Vincenzo Fasolo. In Disegnare. Idee immagini, a. $X X I V$, n. 48, pp. 56-67.

Frey D. (1926). Architettura barocca. Roma-Milano: Soc. Ed. Arte Illustrata.

Giovannoni G. (1922). Tra la cupola di Bramante e quella di Michelangelo. In Architettura e Arti Decorative, fasc. V.

Giovannoni G. (a cura di). (1932). La Scuola di Architettura di Roma. Roma: Cremonese Editore.

Hempel E. (1926). Francesco Borromini. Roma-Milano: Soc. Ed. Arte Illustrata.

Magni G. (| | | | - |3). |l barocco a Roma nell'architettura e nella scultura decorativa. Torino: C. Crudo \& C.

Mariani V. (1943). Michelangelo e la facciata di San Pietro. Roma: Fratelli Palombi - Editori.

Moretti L. (1927). Canovaccio per un saggio sull'architettura di Michelangelo e del Borromino e su quella barocca in genere; e intorno alla natura dell'architettura e alle possibilità di una nuova critica architettonica. Roma: Archivio Moretti Magnifico.

Moretti L. (1957). Forma come struttura. In Bucci F., Mulazzani M. (a cura di). (2000). Luigi Moretti. Opere e scritti, pp. I82- I84. Milano: Electa.

Moretti L. (1964). Le strutture ideali della architettura di Michelangelo e dei barocchi. In Bucci F., Mulazzani M. (a cura di). (2000). Luigi Moretti. Opere e scritti, pp. 192- 195. Milano: Electa.

Muratore G. (7 dicembre 20 I I). Vincenzo Fasolo. I/ vero maestro di tutti i romani. <https://archiwatch.it/20 I I/I 2/07/vincenzonedawagnerasanluca-lingegnereartista-maestroditutti/> (accessed 202I, January 25).

Ricci C. (1912). Architettura barocca in Italia. Stuttgard: Julius Hoffmann Editore.

Rostagni C. (2006). Moretti, Michelangelo e il barocco. In Casabella, a. LXX, n. 6, pp. 8 I-85.

Vasari G. (20 I2). Le vite.Traduzione in italiano contemporaneo di Marco Cavalli.Vicenza Colla Editore. [Prima Ed. Le vite de' più eccellenti pittori, scultori e architettori. I550].

\section{Authors}

Marco Carpiceci, Sapienza Università di Roma, marco.carpiceci@uniroma l.it

Antonio Schiavo, Sapienza Università di Roma, antonio.schiavo@uniromal.it

To cite this chapter. Carpiceci Marco, Schiavo Antonio (2021). La facciata della Basilica di San Pietro: connessioni tra Luigi Moretti e Alberto Carpiceci/ The facade of St. Peter's Basilica: connections between Luigi Moretti and Alberto Carpiceci. In Arena A., Arena M., Mediati D., Raffa P. (a cura di). Connettere. Linguaggi Distanze Tecnologie. Atti del $42^{\circ}$ Convegno Internazionale dei Docenti delle Discipline della Rappresentazione/ Connecting. Languages Distances Technologies. Proceedings of the $42^{\text {th }}$ International Conference of Representation Disciplines Teachers. Milano: FrancoAngeli, pp. 353-370. 